\title{
Correlation of Hematological Parameters, Imaging Results, and Clinical Findings in Primary Headache Disorders
}

\author{
Primer Baş A ̆grılarında Hematolojik Parametreler ve Görüntüleme Bulgularının Klinik \\ ile Korelasyonu
}

(1) Zehra Arıkan1, (1) Saliha Yeter Amasyalı2, (1) Ali Akyol1

${ }^{1}$ Adnan Menderes University Faculty of Medicine, Department of Neurology, Aydin, Turkey

2Adnan Menderes University Faculty of Medicine, Department of Physical Medicine and Rehabilitation, Division of Algology, Aydin, Turkey

\begin{abstract}
Objective: Headache is the most common and challenging neurologic problem in society. There is a relationship between hematologic parameters and headache disorders. White matter lesions are known to be common in migraine. In this study, we aimed to evaluate the hematologic parameters in migraine and tension-type headache, and assessed the correlation of these parameters with headache characteristics and neuroimaging findings.

Materials and Methods: The medical records of patients from the neurology outpatient clinic in Adnan Menderes University Faculty of Medicine between December $1^{\text {st }}$, 2015, and December $1^{\text {st }}$, 2016, were retrospectively reviewed. Six hundred thirty-nine patients aged 18-65 years were included. Two hundred seventy-two were diagnosed as having migraine and 323 had tension-type headache according to the IHS 2013 Beta version. The initial hematologic parameters were studied. Patients who had brain magnetic resonance imaging (MRI) were examined separately.

Results: Patients were classified according to their headache types. Age, sex, pain frequency, headache severity, and hematologic parameters were recorded. There was no significant difference between the two groups in terms of hematologic parameters ( $>0.05)$ and there was a negative correlation between pain frequency and headache severity $(\mathrm{p}<0.05)$. White matter lesions were more common in migraine cases, compatible with the literature. In patients with migraine with white matter lesions, hemoglobin, hematocrit, and mean corpuscular volume were positively correlated with the frequency of attacks $(\mathrm{p}<0.05)$.

Conclusion: We observed no relationship between migraine and GTA and hematologic parameters. This may be due to the role of inflammatory processes in both groups. The absence of significant differences in MRI findings may be related to the inadequate number of patients. Studies involving control groups with larger cohorts may be more elucidative.
\end{abstract}

Keywords: Migraine, tension-type headache, hematologic parameters, white matter lesions

$\ddot{O} \mathbf{z}$

Amaç: Baş ă̆rısı toplumdaki en yaygın ve en zorlu nörolojik sorundur. Hematolojik parametreler ile baş ağrısı bozuklukları arasında bir ilişki olduğu açıktır. Beyaz madde lezyonlarının migrende yaygın olduğu bilinmektedir. Bu çalışmada migren ve gerilim tipi baş ağrısında hematolojik parametreleri değerlendirmeyi amaçladık ve bu parametrelerin baş ağrısı özellikleri ile nörogörüntüleme bulguları arasındaki ilişkiyi değerlendirdik. Gereç ve Yöntem: Adnan Menderes Üniversitesi Tip Fakültesi’nde 1 Aralık 2015-1 Aralık 2016 tarihleri arasında nöroloji polikliniğinden gelen hastaların kayıtları retrospektif olarak incelendi. 18-65 yaşları arasında 639 hasta çalışmaya dahil edildi. IHS 2013 Beta sürümüne göre 272'sine migren tanısı konuldu ve 323 'ünde gerilim tipi baş ă̆rısı vardı. İlk hematolojik parametreler incelendi. Beyin manyetik rezonans görüntülemesi (MRG) olan hastalar ayrı ayrı incelendi. Bulgular: Hastalar baş ağrısı tiplerine göre sınıflandırıldı. Yaş, cinsiyet, ağrı sıklı̆̆ı, baş ağrısı şiddeti ve hematolojik parametreler kaydedildi. İki grup arasında hematolojik parametreler açısından anlamlı fark yoktu (p>0,05) ve ağr1 sıklığ ile baş ağrısı şiddeti arasında negatif korelasyon vardı $(\mathrm{p}<0,05)$. Beyaz cevher lezyonları literatürle uyumlu olarak migren olgularında daha sıkt1. Beyaz cevher lezyonlu migren hastalarında, hemoglobin, hematokrit ve ortalama hücre hacmi atak sıklığ1 ile pozitif korelasyon gösterdi ( $\mathrm{p}<0,05$ ). Sonuç: Migren ve GTA ile hematolojik parametreler arasında herhangi bir ilişki gözlenmedi. Bu, her iki gruptaki enflamatuvar süreçlerin rolüne bağlı olabilir. MRG bulgularında önemli farklılıkların olmaması, yetersiz hasta sayısıyla ilişkili olabilir. Daha geniş kohortlu kontrol grubunu içeren çalışmalar daha aydınlatıcı olabilir.

Anahtar Kelimeler: Migren, gerilim tipi baş ağrısı, hematolojik parametreler, beyaz cevher lezyonları

Address for Correspondence/Yazışma Adresi: Zehra Arıkan MD, Adnan Menderes University Faculty of Medicine, Department of Neurology, Aydin, Turkey Phone: +90 5368891516 E-mail: zehra_arikan@hotmail.com ORCID: orcid.org/0000-0003-3138-2315

Received/Gelis Tarihi: 14.07.2020 Accepted/Kabul Tarihi: 05.12.2020

${ }^{\circ}$ Copyright 2021 by Turkish Neurological Society

Turkish Journal of Neurology published by Galenos Publishing House. 


\section{Introduction}

Headache is a socioeconomically important health problem because it is a frequent and repeating issue in society, and it also results in losses in labor force and affects quality of life. Headaches are considered to have two types, which are primary and secondary headaches. Primary headaches have no underlying causes and secondary headaches are due to secondary causes. In primary headaches, tension-type headache (TTH) is the most common, with a rate of $31.7 \%$, followed by migraine at $16.4 \%(1,2)$.

It is known that there is a relation between hematologic parameters and headaches. In general, this has been associated with anemia, increased blood viscosity, and another similar factor. Few studies have investigated the relationship between hematologic parameters and migraine and TTH. New studies have shown that there is a relation between silent white matter lesion load and migrainous cases. Also, studies have shown that migraine is a risk factor for stroke in young people and migraine has a higher incidence of posterior circulation stroke. There are no studies that investigate migraine and TTH differences in silent white matter lesions. In this study, we compared hematologic parameters [hemoglobin ( $\mathrm{Hb})$, hematocrit (Hct), mean cell hemoglobin $(\mathrm{MCH})$, mean cell hemoglobin concentration (MCHC), mean cell volume (MCV), red cell distribution width (RDW), platelet, mean platelet volume (MPV), leukocyte, lymphocyte, neutrophil, neutrophil/lymphocyte ratio (NLR), platelet/lymphocyte ratio (PLR)] of migraine with TTH-diagnosed patients according to the International Classification of Headache Disorders-III-beta version (ICHD-III- beta), and we aimed to examine the correlation of these parameters with headache characteristics. Another aim was to compare the number of white matter lesions in patients with migraine and TTH using cranial magnetic resonance imaging (MRI) and to evaluate the correlation between hematologic parameters and the headache characteristics of these lesions.

\section{Materials and Methods}

Neurology patients in Adnan Menderes University Faculty of Medicine Hospital were retrospectively observed between December $1^{\text {st }}, 2015$, and December $1^{\text {st }}, 2016$. The study included 639 patients aged 18-65 years, with 272 migraine and 323 TTH diagnoses determined according to the ICHD-III- beta version. Patients with only one type of headache were selected. Patients with no chronic systemic disease, who did not use prophylactic treatment for their headache, no intracranial lesions, cerebrovascular disease, demyelinating disease, and no central nervous system disease such as vasculitis were included. Also, no patients were pregnant during the referral.

The number of painful days, severity, and hemogram of the first visit were recorded within one month. A visual analog scale was used to assess pain severity. Patients with cranial MRI were recorded as imaging findings. MRI lesions were classified as periventricular/subcortical area and anterior/posterior circulation and expressed as a number. The lesion sizes were between 1-10 mm. Ethics Committee Approval was obtained from Adnan Menderes University Faculty of Medicine (protocol no: 2016/1036).

\section{Statistical Analysis}

All data were analyzed using the Statistical Package for the Social Sciences Ver. 18 (SPSS) package program. Data are presented as median \pm standard deviation. The independent samples t-test, chi-square tests, and Pearson and Spearman correlation analyses were performed. The significance limit was accepted as $\mathrm{p}<0.05$. Chi-square analysis was used to investigate the relationship between sex and groups. Age, pain severity, frequency, and hematologic parameters were compared in the migraine and TTH groups using the independent samples t-test. The relationship between hematologic parameters, patient age, pain severity, and frequency in the groups was determined using Pearson correlation analysis.

\section{Results}

Among the 639 patients, 347 (54.3\%) patients had TTH and $292(45.7 \%)$ had migraine. Two hundred sixty-eight $(77.2 \%)$ of the 347 patients with TTH were female and 79 (22.8\%) were male $(\mathrm{p}<0.001)$. Two hundred fifty-nine $(88.7 \%)$ of the 292 patients with migraine were female and $33(11.3 \%)$ patients were male $(\mathrm{p}<0.001)$. Headache was determined to be more frequent in women in both groups (Figure 1).

There was no significant difference in terms of age distribution between the groups $(p>0.05)$. The severity of pain was higher in the migraine group, but this result was not statistically significant $(\mathrm{p}>0.05)$. There was no significant difference between the groups in terms of pain duration $(\mathrm{p}>0.05)$ (Table 1). Also, there was no statistically significant difference in hematologic parameters between the groups ( $p>0.05)$ (Table 2). Hematologic parameters, patient age, pain severity, and frequency were analyzed to determine if there was any correlation between the groups. Hematologic parameters showed no significant findings, but a negative correlation was observed between pain frequency and severity in both groups. The severity of pain increased as the frequency decreased $(\mathrm{p}=0.002)$.

One hundred twenty-four patients had MRI images. Among those, $56(45.2 \%)$ patients had TTH and 68 (54.8\%) had migraine, and 45 had lesions on MRI. Among the patients with lesions, 19 (33.9\%) had TTH and 26 (38.2\%) had migraine (Figure 2). MRI lesions were divided into periventricular-subcortical and anteriorposterior circulation lesions. In the TTH group, 11 patients had only anterior circulation lesions, and eight had anterior and posterior circulation lesions predominantly consisting of anterior circulation lesions. In the migraine group, seven patients had only posterior circulation lesions and 19 had anterior and

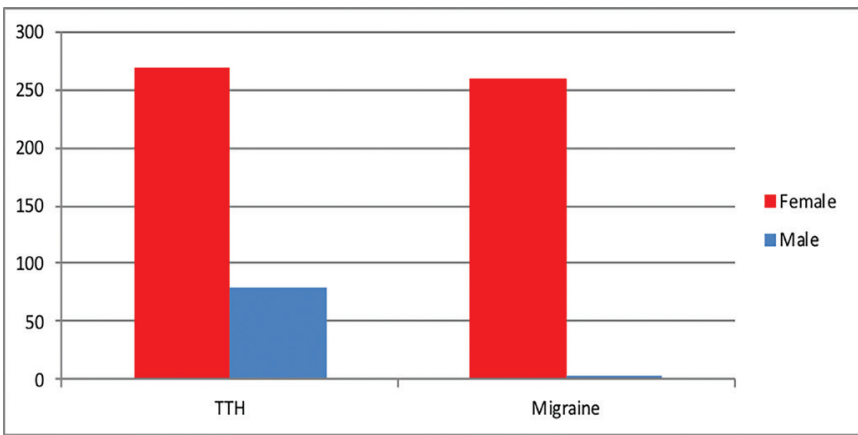

Figure 1. Sex distribution of patients with TTH and migraine TTH: Tension-type headache 
posterior circulation lesions predominantly consisting of posterior circulation lesions. Periventricular lesions were more frequent in migraine headache, but this was not statistically significant $(p=0.286)$. Subcortical lesions were more frequent in migraine headache but they were statistically non-significant $(\mathrm{p}=0.101)$.
Regarding the correlation between age, pain frequency, pain severity, and hematologic parameters in patients with lesions, pain frequency increased with raising $\mathrm{Hb}, \mathrm{Hct}$, and $\mathrm{MCV}$ values in the migraine group $(\mathrm{p}<0.05)$; however, this was not observed in the TTH group $(\mathrm{p}>0.05)$.

Table 1. Age, VAS, and painful days (days/month) for TTH and migraine

\begin{tabular}{|c|c|c|c|c|}
\hline & Groups & Number & Median \pm SD & $\mathrm{p}$ value \\
\hline Age & $\begin{array}{l}\text { TTH } \\
\text { Migraine }\end{array}$ & $\begin{array}{l}347 \\
292\end{array}$ & $\begin{array}{l}36.38 \pm 13.21 \\
35.54 \pm 11.37\end{array}$ & $\begin{array}{l}5.74 \\
0.66\end{array}$ \\
\hline Painful days & $\begin{array}{l}\text { TTH } \\
\text { Migraine }\end{array}$ & $\begin{array}{l}347 \\
292\end{array}$ & $\begin{array}{l}14.65 \pm 9.18 \\
10.66 \pm 8.31\end{array}$ & $\begin{array}{l}0.49 \\
0.48\end{array}$ \\
\hline
\end{tabular}

\begin{tabular}{|c|c|c|c|c|c|}
\hline Parameters & Groups & Number & Median \pm SD & Normal value & $\mathrm{p}$ value \\
\hline \multirow[t]{2}{*}{ Hemoglobin } & TTH & 347 & $13.56 \pm 7.05$ & $11.2-15.7 \mathrm{~g} / \mathrm{dl}$ & 0.38 \\
\hline & Migraine & 292 & $13.43 \pm 7.88$ & - & 0.46 \\
\hline \multirow[t]{2}{*}{ Hematocrit } & TTH & 347 & $43.65 \pm 30.92$ & $37-44 \%$ & 1.66 \\
\hline & Migraine & 292 & $40.22 \pm 4.13$ & - & 0.24 \\
\hline \multirow[t]{2}{*}{$\mathrm{MCV}$} & TTH & 347 & $85.29 \pm 7.91$ & $80.4-95.6 \mathrm{fl}$ & 0.42 \\
\hline & Migraine & 292 & $89.25 \pm 56.01$ & - & 3.27 \\
\hline \multirow[t]{2}{*}{$\mathrm{MCH}$} & TTH & 347 & $29.15 \pm 20.03$ & $27.2-33.5 \mathrm{pg}$ & 1.07 \\
\hline & Migraine & 292 & $27.44 \pm 2.99$ & - & 0.17 \\
\hline \multirow[t]{2}{*}{$\mathrm{MCHC}$} & TTH & 347 & $33.21 \pm 16.51$ & $32.5-35.2 \mathrm{~g} / \mathrm{dl}$ & 0.88 \\
\hline & Migraine & 292 & $32.91 \pm 11.60$ & - & 0.68 \\
\hline \multirow[t]{2}{*}{ RDW } & TTH & 347 & $13.64 \pm 1.58$ & $11.7-14.6$ & 0.08 \\
\hline & Migraine & 292 & $13.84 \pm 1.67$ & - & 0.09 \\
\hline \multirow[t]{2}{*}{ Platelet } & TTH & 347 & $285.45 \pm 71.98$ & $150-35010^{3} \mu \mathrm{l}$ & 3.86 \\
\hline & Migraine & 292 & $287.28 \pm 71.64$ & - & 4.19 \\
\hline \multirow{2}{*}{ MPV } & TTH & 347 & $10.35 \pm 1.06$ & $65-116 \mathrm{ft}$ & 0.06 \\
\hline & Migraine & 292 & $10.33 \pm 1.22$ & $0.5-11.011$ & 0.07 \\
\hline \multirow[t]{2}{*}{ Leukocyte } & TTH & 347 & $8.41 \pm 8.07$ & 3.8-10 $10^{3} \mu \mathrm{l}$ & 0.43 \\
\hline & Migraine & 292 & $7.67 \pm 1.94$ & - & 0.11 \\
\hline \multirow[t]{2}{*}{ Neutrophil } & TTH & 347 & $4.85 \pm 1.84$ & $1.8-6.410^{3} \mu \mathrm{l}$ & 0.09 \\
\hline & Migraine & 292 & $4.57 \pm 1.57$ & - & 0.09 \\
\hline \multirow[t]{2}{*}{ Lymphocyte } & TTH & 347 & $2.41 \pm 1.21$ & $1.2-3.610^{3} \mu \mathrm{l}$ & 0.06 \\
\hline & Migraine & 292 & $2.35 \pm 0.67$ & - & 0.05 \\
\hline \multirow[t]{2}{*}{ NLR } & TTH & 347 & $2.21 \pm 1.18$ & - & 0.06 \\
\hline & Migraine & 292 & $2.11 \pm 1.12$ & - & 0.06 \\
\hline \multirow{2}{*}{ PLR } & TTH & 347 & $130.38 \pm 50.46$ & \multirow{2}{*}{-} & 2.70 \\
\hline & Migraine & 292 & $130.93 \pm 49.87$ & & 2.91 \\
\hline
\end{tabular}




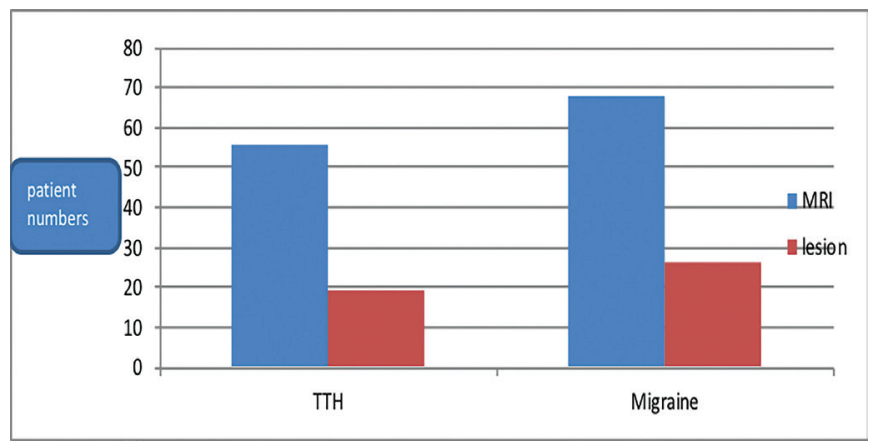

Figure 2. Patients had MRI images and lesions on MRI

MRI: Magnetic resonance imaging, TTH: Tension-type headache

\section{Discussion}

Headaches may vary in each individual in terms of pain frequency and severity. Various studies have been performed to determine the cause of this variability. In some studies, blood viscosity and anemia have been evaluated and their effect on pain was investigated. Additionally, platelet counts and diameters also have been evaluated due to its role in serotonin secretion. The variability of the leukocyte counts has been emphasized considering the release of mediators causing neurogenic inflammation (3). In the present study, our purpose was to analyze hematologic parameters such as $\mathrm{Hb}, \mathrm{Hct}, \mathrm{MCV}, \mathrm{MCH}, \mathrm{MCHC}$, RDW, platelet, MPV, leukocyte, neutrophil and lymphocyte, and to compare the distribution of hematologic parameters in migraine and TTH, and to examine the effects on imaging findings.

As it is known, silent ischemic lesions are more common in the imaging of patients with migraine. No studies have compared MRI lesions between patients with migraine and TTH. In our study, we compared the ischemic lesions in MRI between patients with migraine and TTH and investigated the correlation of these ischemic lesions with hematologic parameters.

It is suggested that there is a relationship between hematologic disorders and headache (3). However, there are a small number of studies on this subject. Migraine headache is frequently associated with hematologic, neurologic, vascular, and cardiac diseases (4). In particular, there are studies on iron deficiency anemia and headache, both of which are common in society $(5,6,7,8,9,10)$. Patients with migraine headache and healthy controls are compared in most studies, few studies have compared tension-type and migraine headaches.

Iron is distributed in various matters in the body such as $\mathrm{Hb}$, myoglobin, cytochromes, and especially in the structure of enzymes responsible for energy production. Iron deficiency affects the body, and iron accumulation causes harmful effects in the body such as neuronal degeneration and cell death (3). There are studies showing that iron accumulation reduces the threshold of triggering headaches by altering the threshold of excitation of neurons (6). It is suggested that high $\mathrm{Hb}$ and Hct levels may cause headache by increasing blood viscosity. Hyperviscosity is thought to cause pain by destroying microcirculation leading to cerebral hypoxia, reactive vasodilatation, and neurogenic inflammation $(10,11)$. Studies have shown that there is a decrease in cerebral blood flow at the height of Hct in migraineurs. Furthermore, it has been shown that there is a $50 \%$ increase in cerebral blood flow after Hct reduction with phlebotomy $(12,13)$. Also, an increase in platelet adhesion contributes to increased viscosity. Demirel et al. (5) reported that the pain frequency increased in a migraine group as the iron-binding capacity decreased and ferritin level increased, and the pain frequency increased as the $\mathrm{Hb}, \mathrm{Hct}$, and ferritin levels decreased in the tension headache group. It is thought that hypoxia occurs in brain tissue and reactive vasodilatation in the intracranial arteries due to low $\mathrm{Hb}$ values, which may be accompanied by an increase in myofascial input and increased pain frequency (5). Aamodt et al. (14) demonstrated that headache frequency was decreased in patients with $\mathrm{Hb}$ levels below $11.5 \mathrm{~g} / \mathrm{dl}$. They also reported no relationship between ferritin levels and headache prevalence (14). In the study of Yildirim et al. (15), MCHC and RDW were found to be higher than in healthy controls in the migraine group. In our study, there was no significant difference in $\mathrm{Hb}, \mathrm{Hct}, \mathrm{MCV}, \mathrm{MCH}, \mathrm{MCHC}$, and RDW values between the migraine and TTH groups. Another finding was that the pain intensity increased as the pain frequency decreased in both groups. This may be related to the development of desensitization in those who have been in pain for a long time, and thus may be related to a milder assessment of their pain.

In the past years, also, nitric oxide synthase, which is believed to play an important role in central sensitization, is present in platelets, suggesting that migraine is a primary platelet dysfunction. However, this hypothesis has not been supported by further studies $(16,17,18)$. Another relationship between platelet biology and migraine may be explained by inflammation. Following the formation of platelet-leukocyte aggregates, many pro-inflammatory cytokines, primarily interleukin (IL)-1, IL-6, IL- 8 and tumor necrosis factor- $\alpha$, may increase and these mediators may contribute to sterile inflammation and pain facilitation in the brain $(19,20,21)$. A number of studies have been conducted to investigate the potential association between platelet biology and migraine, by the presence of frequent headache attacks mimicking migraine in patients who had essential thrombocytosis and significant contribution of cerebral blood flow abnormalities to the pathogenesis of migraine $(18,22,23,24,25,26)$. MPV is regarded as a sign of platelet function and activation. Large platelets have higher thrombosis potential. Several studies have supported the predisposition to platelet aggregation in patients with migraine $(27,28,29,30)$. Different results have been obtained in studies investigating platelet count and MPV in patients with migraine $(31,32,33)$. In our study, there was no statistically significant difference between the platelet counts and MPV values of patients with migraine and TTH. This may be due to the active role of serotonin in the pathophysiology of both headaches.

Migraine attacks are thought to be the result of neurovascular inflammation of the cerebral and extra-cerebral vessels (34). The responses, which are given by leucocytes in circulation, causes an increase in the number of neutrophils and a decrease in the number of lymphocytes. For this reason, the NLR is used as an indicator of inflammation (35). As a subclinical inflammatory marker, NLR has been associated with the prognosis and mortality of many patients. PLR is a sign of severe inflammation and promotes the proliferation of megakaryocytes. NLR has been found as high in migraine studies but no significant difference has been found in PLR $(36,37,38)$. In our study, leukocyte, lymphocyte, neutrophil, 
NLR and PLR were compared between the TTH and migraine groups in the inter-ictal phase. There was no difference between the parameters in the TTH group, but it was found in the migraine group that as the age increased, the PLR value decreased and the PLR value increased with pain frequency. Also, there was no difference between the groups in NLR values. This may be due to the facts that, depending on the retrospective study design, the attacks of patients cannot be assessed and that there are signs of inflammation in both headache groups. Studies involving a healthy control group are needed.

A few studies have shown that asymptomatic white matter lesions in migraineurs are more common than in the normal population. Several pathophysiologic mechanisms have been proposed including migraine-associated oligemia and focal hypoperfusion (37), glutamatergic excitotoxicity (38), immunebased white matter demyelination (39), and mitochondrial dysfunction (40). It has been suggested that migraine recurrent attacks lead to endothelial damage due to inflammatory arteriopathies in the cranial veins, resulting in thrombosis $(41,42)$. In a study by Silvestrini et al. (43), cerebral vasomotor reactivity responses were evaluated in frontal and posterior circulation in patients with migraine during the non-exacerbation period, and when compared with the control group, vasomotor responses to posterior circulation were low and there was no significant difference in the anterior circulation. These data suggest that adaptive cerebral hemodynamic mechanisms are impaired in the posterior circulation (43). In another study, cerebral vascular reactivity induced by L-arginine in PCA was significantly lower in patients with migraine with and without aura than that of the normal population, and this suggests that posterior circulation infarcts may be more frequent in migraineurs (44). In our study, anterior circulation lesions were more frequent in the TTH group, and posterior circulation lesions were observed more frequently in the migraine group; the findings were consistent with the literature $(43,44)$.

Swartz and Kern (45) reviewed seven retrospective studies conducted between 1991 and 2001 in patients with migraine for the evaluation of white matter lesions and found that the white matter lesion risk in patients with migraine was four-fold higher than in the normal population. There are very few studies on white matter lesions and other types of headache. One study showed that white matter lesions did not develop in new daily persistent headache (46). White matter lesions of medication overuse headache and with patients migraine have been compared and no lesions developed in those who did not have a vascular risk factor in the medication overuse headache (47). In our study, white matter lesions in subcortical and periventricular areas in patients with TTH and migraine were compared concerning the number of lesions and pain characteristics. The number of lesions in both regions of the migraine group was higher but not statistically significant. There was no statistically significant difference between white matter lesions and age, pain frequency, pain severity, and hematologic parameters. The pain frequency increased as $\mathrm{Hb}$, $\mathrm{Hct}$, and MCV values increased in the patients with migraine with lesions. This was not been observed in the TTH group. We assume that the increase in pain frequency may trigger the proinflammatory mechanisms and lead to the development or increase the number of white matter lesions in migraine.

\section{Conclusion}

As a result, we observed no relationship between migraine and TTH and hematologic parameters. This may be due to the role of inflammatory processes in both groups. The absence of significant differences in MRI findings may be related to the inadequate number of patients. Studies involving control groups with larger cohorts may be more elucidative.

\section{Ethics}

Ethics Committee Approval: Ethics Committee Approval was obtained from Adnan Menderes University Faculty of Medicine (protocol no: 2016/1036).

Informed Consent: Retrospective study.

Peer-review: Externally peer-reviewed.

\section{Authorship Contributions}

Surgical and Medical Practices: Z.A., A.A., Concept: A.A., Design: Z.A., S.Y.A., A.A., Data Collection or Processing: Z.A., Analysis or Interpretation: A.A., S.Y.A., Literature Search: Z.A., A.A., Writing: Z.A., S.Y.A.

Conflict of Interest: The authors have not declared any conflict of interest related to this article.

Financial Disclosure: No financial support was received from any institution or person for our study.

\section{References}

1. Karlı N, Zarifoğlu M, Erteş M, et al. Economic impact of primary headaches in Turkey: a university hospital based study: part II. J Headache Pain 2006;7:75-82.

2. Siva A. Başağrisı Epidemiyolojisi. Turkiye Klinikleri J Neur 2003;1:94-97.

3. Silberstein SD, Lipton RB, Goadsby P. Gerilim tipi başağrısı- tanı ve tedavi. In: Ertaş M, Demir G, (eds). Klinik uygulamada baş ağrısı. İstanbul: Yelkovan Yayıncilık; 2004:21-34.

4. Scher AI, Bigal ME, Lipton RB. Comorbidity of migraine. Curr Opin Neurol 2005;18:305-310.

5. Demirel H, Emre U, Atasoy HT, Ünal A, Ankaralı H. The association between haematological parameters, migraine and tension type headache. Turk J Neurol 2008;14:394-398.

6. Hagen K, Stovner LJ, Asberg A, et al. High headache prevalence among women with hemochromatosis: the Nord-Trondelag health study. Ann Neurol 2002;51:786-789.

7. Welch KMA, Nagesh V, Aurora SK, Gelman N. Periaqueductal gray matter dysfunction in migraine. Cause or burden of illness? Headache 2001;41:629637.

8. Kruit MC, Launer LJ, Overbosch J, vanBuchem MA, Ferrari MD. Iron accumulation in deep brain nuclei in migraine: a population-based magnetic resonance imaging study. Cephalalgia 2009;29:351-359.

9. Kruit MC, van Buchem MA, Launer LJ, Terwindt GM, Ferrari MD. Migraine is associated with an increased risk of deep white matter lesions, subclinical posterior circulation infarcts and brain iron accumulation: the populationbased MRI CAMERA study. Cephalalgia 2010;30:129-136.

10. Blumenthal DT, Glenn MJ. Neurological manifestation of hematological disorders. Neurol Clin 2002;20:265-281.

11. Spierings EL. Pathogenesis of the migraine attack. Clin J Pain 2003;19:255262.

12. Thomas DJ, Marshall J, Russell RW, et al. Effect of haematocrit on cerebral blood-flow in man. Lancet 1977;2:941-943.

13. Grotta J, Ackerman R, Correia J, Fallick G, Chang J. Whole blood viscosity parameters and cerebral blood flow. Stroke 1982;13:296-301.

14. Aamodt AH, Borch-Iohnsen B, Hagen K, et al. Headache prevalence related to haemoglobin and ferritin. Cephalalgia 2004;24:758-762.

15. Yıldırım Baş F, Demirci S, Arslan B. The relationship between headache features and haematological parameters in migraine patients. Euras J Fam Med 2015;4:53-56. 
16. Hao JX, Xu XJ. Treatment of a chronic allodynia-like response in spinally injured rats: effects of systemically administered nitric oxide synthase inhibitors. Pain 1996;66:313-319.

17. Kitto KF, Haley JE, Wilcox GL. Involvement of nitric oxide in spinally mediated hyperalgesia in the mouse. Neurosci Lett 1992;148:1-5.

18. D'Andrea G, Cananzi AR, Perini F, Hasselmark L. Platelet models and their possible usefulness in the study of migraine pathogenesis. Cephalalgia 1995; 15:265-271.

19. Schs D, Cunha FQ, Poole S, Ferreira SH. Tumour necrosis factor-alpha, interleukin- 1beta and interleukin-8 induce persistent mechanical nociceptor hypersensitivity. Pain 2002;96:89-97.

20. Burstein R, Jakubowski M, Rauch SD. The science of migraine. J Vestib Res 2011;21:305-314.

21. Yan J, Melemedjian OK, Price TJ, Dussor G. Sensitization of dural afferents underlies migraine-related behavior following meningeal application of interleukin-6 (IL-6). Mol Pain 2012;8:6.

22. Hanington E, Jones RJ, Amess JA, Wachowicz B. Migraine: a platelet disorder. Lancet 1981;2:720-723.

23. Hanington E, Jones RJ, Amess JA. Platelet nucleotides in migraine. Lancet 1982;2:437-440.

24. Hanington E, Jones RJ, Amess JA. Migraine and platelets. Lancet 1982;1:1248.

25. Manotti C, Quintavalla R, Manzoni GC. Platelet activation in migraine. Thromb Haemost 1983;50:758.

26. De Matteis G, Tozzi-Ciancarelli MG, Calisse P, et al. Platelet changes in classic migraine. Ital J Neurol Sci 1993;14:207-210.

27. Lechner H, Ott E, Fazekas F, Pilger E. Evidence of enhanced platelet aggregation and platelet sensitivity in migraine patients. Cephalalgia 1985;5(Suppl 2):89-91.

28. Carrieri P, Sorge F, Orefice G, De Feo S. Platelet function in childhood migraine. Cephalalgia 1985;5(Suppl 2):99-101.

29. Sarchielli P, Alberti A, Coppola F, et al. Platelet-activating factor (PAF) in internal jugular venous blood of migraine without aura patients assessed during migraine attacks. Cephalalgia 2004;24:623-630.

30. Tietjen GE, Al-Qasmi MM, Athanas K, Utley C, Herial NA. Altered hemostasis in migraineurs studied with a dynamic flow system. Thromb Res 2007;119:217-222.

31. Kurth T, Gaziano JM, Cook NR, et al. Migraine and risk of cardiovascular disease in women. JAMA 2006;296:283-291.
32. Pradalier A, Abuaf N, Launay JM, Vincent D. Platelet size and volume distribution measured by automated platelet analyzer. Cephalalgia 1992;12:321-322.

33. Varol S, Akıl E, Çevik MU, et al. Investigation of mean platelet volume and platelet count in the blood of patients with migraine. Turk J Neurol 2013;19:90-92.

34. Bolay H, Reuter U, Dunn K. Intrinsic brain activity triggers trigeminal meningeal afferents in a migraine model. Nat Med 2002;8:110-112.

35. Zhang X, Levy D, Noseda R, et al. Activation of meningeal nociceptors by cortical spreading depression: implications for migraine with aura. J Neurosci 2010;30:8807-8814.

36. Karabulut Uçar K, Eğercioğlu TU, Uyar M, Uçar Y. The change of neutrophils/lymphocytes ratio in migraine attacks: A case-controlled study. Ann Med Surg (Lond) 2016;10:52-56.

37. Kruit MC, Launer LJ, Ferrari MD, Buchem MA. Brain stemand cerebellar hyperintense lesions in migraine. Stroke 2006;37:1109-1112.

38. Longoni M, Ferrarese C. Inflammation and excitotoxicity: role in migraine pathogenesis. Neurol Sci Suppl 2006;2:S107-S110.

39. Robbins L, Friedman H. MRI in migraineurs. Headache 1992;32:507-508.

40. Sparaco M, Feleppa M, Lipton RB, Rapoport AM, Bigal ME. Mitochondrial dysfunction in migraine: evidence and hypotheses. Cephalalgia 2006;26: 361-372.

41. Moskowitz MA, Macfarlane R. Neurovascular and molecular mechanisms in migraine headaches. Cerebrovasc Brain Metab Rev 1993;5:159-177.

42. Welch KM. Stroke and migraine-the spectrum of cause and effect. Funct Neurol 2003;18:121-126.

43. Silvestrini M, Baruffaldi R, Bartolini M, et al. Basilar and middle cerebral artery reactivity in patients with migraine. Headache 2004;44:29-34.

44. Perko D, Pretnar-Oblak J, Sabovic M, Zvan B, Zaletel M. Cerebrovascular reactivity to 1 -arginine in the anterior and posterior cerebral circulation in migraine patients. Acta Neurol Scand 2011;124:269-274.

45. Swartz RH, Kern RZ. Migraine is associated with MRI white matter abnormalities: a meta-analysis. Arch Neur 2004;61:1366-1338.

46. Rozen TD. New daily persistent headache: A lack of an association with white matter abnormalities on neuroimaging. Cephalalgia 2016;36:987992.

47. Zheng Z, Xiao Z, Shi X, et al. White matter lesions in chronic migraine with medication overuse headache: a cross-sectional MRI study. J Neurol 2014;261:784-790. 